\title{
DE BRUGSE SCHILDER PIETER VANDER BOEIERIE 1548-1550
}

\author{
A. SCHOUTEET $^{\circ}$
}

Pieter vander Boeierie werd op 14 mei 1548 als meester-schilder in het ambacht van de beeldenmakers en de zadelmakers, waaronder de schilders te Brugge ressorteerden, opgenomen. Zijn inschrijving in de gildeboeken van deze corporatie vermeldt dat hij een "vreemde" was, d.w.z. iemand die noch een zoon van een vrijmeester van dit ambacht was, noch zijn leertijd te Brugge had doorgemaakt. In ieder geval was hij poorter van de stad, wat een essentiële voorwaarde was om als lid van de beeldenmakers en de zadelmakers te kunnen aanvaard worden. Het Brugse poorterrecht heeft hij zeker niet moeten verkrijgen door koop, want noch in de stadsrekeningen, noch in de poorterboeken, noch in de feriën van de stadsthesauriers, waarin de nieuwe poorters door koop staan geregistreerd, is van Pieter vander Boeierie een spoor te vinden. Poorter is hij derhalve geworden ofwel door geboorte ofwel door huwelijk met een Brugse poorteres ${ }^{1}$.

Voor Pieter vander Boeierie was geen lange en vruchtbare loopbaan weggelegd. Kort vóór 25 augustus 1550 is hij inderdaad reeds gestorven. Zijn afsterven staat aangetekend in het obituarium van de beeldenmakers en de zadelmakers tussen de overlijdens van twee bekende Brugse schilders : Ambrosius Benson ( $\dagger$ ca. 12 januari 1550) ${ }^{2}$ en Adriaan Isenbrant († kort vóór 21 juli 1551) ${ }^{3}$. Naar aanleiding van zijn dood werden overigens op 25 augustus 1550 door de stedelijke overheid

- Wijlen ere-stadsarchivaris van Brugge.

1. Over het poorterschap te Brugge en de manieren waarop men het kon verwerven, zie : R.A. PARMENTIER, Indices op de Brugse poorterboeken, dl. I, Brugge, 1938, p. VIII en vlg.

2. Over de sterfdatum van Ambrosius Benson, zie : R.A. PARMENTIER, Bescheiden omtrent Brugsche schilders van de I6e eeuw, in Handelingen van het Genootschap "Société d'Emulation" te Brugge, LXXX (1937), p. 89-90.

3. Over de sterfdatum van Adriaan Isenbrant, zie : R.A. PARMENTIER, Bronnen voor de geschiedenis van het Brugsche schildersmilieu in de XVIe eeuw, in Belgisch tijdschrift voor oudheidkunde en kunstgeschiedenis, IX (1939), p. 229. 
voogden aangesteld over zijn minderjarig dochtertje Pierine, dat hij had uit zijn huwelijk met Elizabeth Coolman.

Wegens de zeer korte tijdspanne - amper twee jaar - waarin Pieter vander Boeierie als vrijmeester-schilder te Brugge kan gewerkt hebben, is de kans meerdere bijzonderheden over zijn persoon te vinden uiteraard gering. De uiteenlopende schrijfwijzen van zijn familienaam zullen de opsporingen ook niet vergemakkelijken. Onderhavige schilder hebben we slechts driemaal in de documenten aangetroffen en telkens werd zijn naam op een verschillende wijze geschreven, te weten : vander Boeierie, vander Boeyerie en Baugerye. Om dezelfde redenen zal wellicht nooit iets over zijn artistieke bedrijvigheid aan het licht komen ${ }^{4}$.

\section{BIJLAGE}

1550 augustus 25. - Jan Vervake en Pieter vander Cruuce worden aangesteld tot voogden over Pierine, het minderjarige dochtertje van wijlen de schilder Pieter vander Boeierie en Elizabeth Coolman.

Jan Vervake, baerdemakere, juravit tutor in stede van Willem van Hessche, vluchtich, verlaten, met Pietre vander Cruuce, te vooren voochd van Pierinkin, Pietre Baugerye schilders dochtre by Lisbette Coolmans, uxor. Actum den XXV in ougst XV' $\mathrm{C}$, present : Bambeke, raedt, Mouscron ende Cabootre, scepenen.

- Brugge, Stadsarchief, r. 205 : Wezerij voogdijschappen, 1545$1558, \mathrm{f}^{\circ} 72 \mathrm{v}, \mathrm{nr} .2$.

4. Over Pieter vander Boeierie, zie : C. VANDEN HAUTE, La corporation des peintres de Bruges, Brugge-Kortrijk, z.j. [1913], p. 84 b, 201 b. 